Gelanggang Olahraga: Jurnal Pendidikan Jasmani dan Olahraga

Volume 3, Nomor 1, Juli-Desember 2019

e-ISSN : 2597-6567

p-ISSN : 2614-607X

DOI : https://doi.org/10.31539/jpjo.v3i1.871

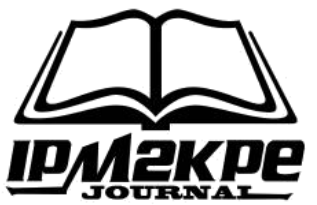

\title{
PELAKSANAAN EKSTRAKURIKULER BOLA VOLI PADA SEKOLAH DASAR
}

\author{
Muhammad Supriyadi \\ Dosen STKIP-PGRI Lubuklinggau \\ Muhammadsupriyadi.030190@gmail.com
}

\begin{abstract}
ABSTRAK
Penelitian ini bertujuan untuk menggambarkan tentang pelaksanaan ekstrakurikuler bolavoli di SDN 85 Lubuklinggau. Populasi penelitian ini adalah semua siswa dan siswi yang ikut dalam pelaksanaan ekstrakurikuler bolavoli yakni berjumlah sebanyak 30 orang. Sampel dalam penelitian diambil menggunakan teknik total sampling dimana sampel dalam penelitian ini adalah keseluruhan dari populasi penelitian yang berjumlah 30 orang. Teknik pengumpulan data menggunakan angket instrument penelitian dengan skala likert. Hasil analisis data, 1) tingkat capaian motivasi siswa dalam pelaksanaan ekstrakurikuler Bolavoli berada pada klasifikasi cukup, yaitu dengan tingkat capaian jawaban responden mencapai $60 \%$, 2) tingkat capaian sarana dan prasarana dalam pelaksanaan ekstrakurikuler bolavoli berada pada klasifikasikan baik, yaitu dengan tingkat capaian sebesar $62 \%$. Simpulan, pelaksanaan ekstrakurikuler bola voli dalam kategori baik.
\end{abstract}

Kata Kunci : Pelaksanaan, Ekstrakurikuler, Bola Voli

\section{ABSTRACT}

This study aims to describe the implementation of bolavoli extracurricular in SDN 85 Lubuklinggau. The population of this study were all students who participated in the implementation of volleyball extracurricular totaling 30 people. The sample in this study was taken using a total sampling technique where the sample in this study was the entirety of the research population of 30 people. Data collection techniques using a research instrument questionnaire with a Likert scale. The results of data analysis, 1) the level of achievement of students 'motivation in the implementation of volleyball extracurricular activities is in the classification of Enough, namely the level of achievement of respondents' answers reached 60\%, 2) the level of achievement of facilities and infrastructure in the implementation of volleyball extracurricular activities is in the classification of Good, ie with a level of achievement of $62 \%$. Conclusion, volleyball extracurricular implementation is in good category.

Keywords: Implementation, Extracurricular, Volleyball 


\section{PENDAHULUAN}

Salah satu bidang pendidikan yang mendapat perhatian dari pemerintah adalah Pendidikan jasmani, olahraga dan kesehatan yang merupakan bidang pelajaran di sekolah. Dalam kurikulum tujuan dari pembelajaran pendidikan jasmani, olahraga dan kesehatan ini adalah :

1)Mengembangkan keterampilan pengelolaan diri dalam upaya pengembangan dan pemeliharaan kebugaran jasmani serta pola hidup sehat melalui berbagai aktifitas jasmani dan olahraga, 2) Meningkatkan pertumbuhan fisik dan pengembangan psikis yang lebih baik, 3) Meningkatkan kemampuan dan keterampilan gerak dasar, 4) meletakkan landasan karakter moral yang kuat melalui internalisasi nilai-nilai yang terkandung dalam pendidikan jasmani, olahraga dan kesehatan, 5) mengembangkan sikap sportif, jujur, disiplin, bertanggung jawab, kerjasama, percaya diri, demokratis, 6) mengembangkan keterampilan untuk menjaga keselamatan diri, orang lain dan lingkungan, 7) memahami konsep aktivitas jasmani an olahraga di lingkungan yang bersih sebagai informasi untuk mencapai pertumbuhan fisik yang sempurna, pola hidup sehat dan kebugaran, terampil serta memiliki sikap yang positif.

Dari kutip di atas, jelaslah bahwa banyak sekali manfaat dari pendidikan jasmani yang sangat berarti bagi seseorang, apa bila tujuan dari pendidikan jasmani, olahraga dan kesehatan betul-betul dapat dipahami, dimengerti dan dilaksanakan dengan baik, terutama bagi siswa. Di samping berguna untuk perkembangan fisik dan meningkatkan kebugaran jasmani serta kesehatan yang lebih baik, juga dapat memperkaya keterampilan gerak dasar. Selanjutnya hal ini bermanfaat untuk menjaga diri, orang lain dan lingkungan karena dalam aktivitas jasmani, olahraga dan kesehatan banyak mengandung nilai-nilai positif yang berguna dalam kehidupan.

Selanjutnya di sekolah-sekolah, khususnya pada Sekolah Dasar (SD) aktivitas atau kegiatan yang harus dilakukan oleh siswa terdiri dari: intrakurikuler, kokurikuler dan ekstrakurikuler. Umar (1998) menjelaskan pengertian dari masing kegiatan tersebut adalah:

1) Kegiatan intrakurikuler adalah kegiatan pengajaran ang rutin dilakukan oleh siswa pada jam sekolah dengan alokasi waktu yang telah ditentukan, 2) Kegiatan kokurikuler adalah kegiatan mempelajari bahan pengajaran yang diberikan diluar jam pelajaran tatap muka sebagai tugas atau pekerjaan rumah, untuk menunjang bahan pengajaran yang diberikan dalam tatap muka tersebut, 3) Kegiatan ekstrakurikuler adalah merupakan kegiatan yang dilakukan di luar jam pelajaran tatap muka (termasuk diwaktu libur).

Berpedoman pada kutipan di atas, maka dapat diambil suatu kesimpulan bahwa, ada tiga bentuk atau jenis kegiatan yang harus diikuti siswa di sekolah. Masing-masing jenis kegiatan tersebut mempunyai tujuan yang berbeda-beda, akan tetapi secara keseluruhan merupakan upaya dan usaha dalam meningkatkan dan mengembangkan kemampuan atau potensi yang dimiliki siswa. Begitu juga dalam mengembangkan kemampuan dan keterampilan dalam cabang olahraga, khusus melalui kegiatan ekstrakurikuler. 
SDN 85 Lubuklinggau, cabang-cabang olahraga yang dilaksanakan dalam kegiatan ekstrakurikuler pada semester Januari-Juni tahun 2018 antara lain: sepak bola, pencak silat dan bolavoli. Kegiatan ekstrakurikuler untuk masing-masing tersebut jadwal dan jumlah pertemuannya sudah diatur sedemikian rupa, yakni diluar jam pelajaran wajib. Khusus untuk cabang olahraga bolavoli dilaksanakan dua kali dalam seminggu yaitu hari rabu dan jumat sore jam 16.00 WIB.

Menurut Erianti (2004) olahraga permainan bolavoli merupakan salah satu cabang olahraga beregu, yang tiap regunya terdiri dari 6 orang dan dimainkan dalam lapangan yang berukuran dengan panjang 18 meter dan lebar 9 meter. Dengan ketinggian net 2,43 untuk putra dan 2,24 untuk putri, memakai bola ukuran nomor 5 dengan berat 260-280 gram dan memakai peraturan perwasitan serta peraturan pertandingan yang resmi dan ditetapkan oleh Persatuan bolavoli seluruh Indonesia (PBVSI).

Melalui kegiatan ekstrakurikuler bolavoli diharapkan para siswa dapat menguasai keterampilan dan memanfaatkan aktifitas secara baik dalam rangka meningkatkan kesegaran jasmani. Bahkan dapat juga dikatakan kegiatan ekstrakurikuler bolavoli ini dapat mengembangkan bakat dan minat siswa dalam usaha meningkatkan kemampuan dan keterampilan bermain bolavoli. Hasil penelitian Fatahillah (2018) menunjukan variabel bebas kelincahan memberikan kontribusi terhadap kemampuan dribbling ekstrakurikuler bolabasket

Disamping itu dapat menjaring bibit-bibit atlet, yang nantinya akan diarahkan perkembangan dan pembinaanya secara lebih baik dengan tujuan atau sasaran pada olahraga prestasi. Selanjutnya hal ini merupakan sebagai bekal yang berguna bagi siswa untuk lebih dapat mengembangkan dirinya, setelah mereka menyelesaikan program studinya nanti. Dalam arti lain mereka tidak canggung lagi untuk terjun ketengah-tengah masyarakat dan juga bermanfaat untuk melanjutkan pendidikan ketingkat tinggi yang relevan.

Dalam melaksanakan kegiatan ekstrakurikuler bolavoli tentunya sangat didukung oleh banyak faktor antara lain: pengetahuan dan keterampilan serta wawasan yang dimiliki guru pendidikan jasmani sebagai guru pembimbing/pelatih kegiatan, perencanaan program latihan yang baik, ketersediaan sarana dan prasarana yang dibutuhkan, motivasi siswa dalam mengikuti kegiatan, bakat dan minat, kondisi fisik yang dimiliki siswa, dukungan pihak sekolah dan orang tua siswa.

Hasil penelitian Sovensi (2018) terdapat hubungan yang signifikan antara koordinasi mata tangan dan ekstensi togok secara bersama-sama dengan ketepatan Smash. Hasil penelitian Supriyanto (2018) pemain yang memiliki kecepatan reaksi tinggi lebih efisien dilatih dengan metode latihan beban. Hasil penelitian Sovensi (2019) kondisi fisik pemain bola voli klub di Kota Lubuklinggau dalam kategori baik. Penelitian ini menekankan pada pelaksanaan kegiatan ekstrakurikuler bola voli pada sekolah dasar, sebab pelaksanaan kegiatan ekstrakurikuler bolavoli membutuhkan dukungan, agar dalam pelaksanaannya dapat berjalan dengan baik.

Berdasarkan pengamatan penulis dan informasi yang diterima dari guru pendidikan jasmani olahraga dan kesehatan, pelaksanaan kegiatan ekstrakurikuler bolavoli belumlah berjalan seperti apa yang diharapkan. Hal ini terlihat kehadiran siswa dalam mengikuti kegiatan ekstrakurikuler bolavoli semakin hari semakin sedikit, dari jumlah siswa yang terdaftar yaitu sebanyak 30 orang namun tidak 
secara keseluruhan hadir disetiap jadwal yang sudah ditetapkan yakni dua kali dalam seminggu. Bahkan dalam melaksanakan latihan terkesan kurang bersemangat, malas bergerak dan apa lagi pada saat disuruh pemanasan.

\section{KAJIAN TEORI}

\section{Hakekat Permainan Bolavoli}

Bolavoli merupakan permainan beregu atau kelompok, masing-masing regu terdiri dari enam orang pemain.. Permainan bolavoli dimainkan di atas lapangan yang berukuran panjang 18 meter dan lebar 9 meter dengan ketinggian net 2,43 meter untuk putra dan 2,24 meter untuk putri. Peraturan yang dipakai adalah peraturan resmi dari Persatuan Bolavoli Seluruh Indonesia (PBVSI), baik peraturan perwasitan maupun peraturan pertandingan yang berlaku.

\section{Hakekat Kegiatan Ekstrakurikuler}

Kegiatan ekstrakurikuler merupakan bagian dari semua kegiatan yang ada di sekolah; wajib diikuti oleh siswa sesuai dengan pilihan mereka dan kegiatan tersebut dilaksanakan diluar jam pelajaran, bahwa melalui kegiatan ekstrakurikuler dapat menjaring siswa-siswi yang memiliki minat dan bakat, khususnya dalam cabang olahraga tertentu, misalnya olahraga permainan bolavoli. Begitu juga dengan pelaksanaan ekstrakurikuler bolavoli di SDN 85 Lubuklinggau. Dalam pelaksanaannya yang dipengaruhi banyak faktor dalam mencapai tujuan yang diinginkan, faktor tersebut antara lain faktor motivasi siswa, sarana dan prasarana.

\section{Hakekat Motivasi}

Motivasi yaitu usaha yang disadari untuk menggerakkan, mengarahkan dan menjaga tingkah laku seseorang agar ia terdorong untuk bertindak melakukan sesuatu, sehingga mencapai hasil/tujuan tertentu. Fungsi motivasi adalah mendorong manusia atau seseorang untuk berbuat, menentukan arah perbuatan, untuk mencapai tujuan dan menyeleksi perbuatan yaitu perbuatan mana yang akan dikerjakan.

Motivasi dapat diklasifikasikan atas dua bagian yaitu motivasi instrinsik dan ekstrinsik. Motivasi instrinsik yaitu motivasi yang munculnya dari dalam diri sendiri atau dapat juga dikatakan seorang siswa terlibat dalam suatu kegiatan bila menurutnya bermanfaat dan atas keinginan sendiri dia mengikuti kegiatan tersebut. Sedangkan motivasi ekstrinsik adalah motivasi yang keberadaannya karena pengaruh dari luar, bukan merupakan perasaan atau keinginan sendiri, contohnya seseorang siswa ikut latihan bolavoli dalam kegiatan ekstrakurikuler hanya karena diajak teman atau dorongan dari orang tua yang menginginkan anaknya berprestasi.

\section{Hakekat Sarana dan Prasarana}

Proses belajar dan latihan dalam kegiatan ekstrakurikuler akan berjalan lancar dengan baik, apabila ditunjang oleh sarana dan prasarana yang memadai, baik dari segi kuantitas maupun dari segi kualitasnya.Demi kelancaran proses belajar dan latihan dalam suatu kegiatan ekstrakurikuler di sekolah, khususnya dalam pelaksanaan ekstrakurikuler bolavoli. 


\section{METODE PENELITIAN}

Penelitian ini adalah penelitian deskriptif kuantitatif maksudnya adalah untuk mengumpulkan informasi mengenai suatu objek dengan menggambarkan apa adanya. Jenis data ini terdiri dari data primer dan data sekunder. Data primer adalah Jenis data dalam penelitian data yang diambil langsung dari sampel yang teliti, sedangkan data sekunder adalah data yang diperoleh dari administrasi sekolah sebagai pendukung atau tambahan penguat data yang akan diambil. Sumber data berasal dari siswa-siswi SDN 85 Lubuklinggau yang mengikuti ekstrakurikuler bolavoli

Untuk memperoleh hasil data mengenai pelaksanaan kegiatan ekstrakurikuler bolavoli, maka alat yang digunakan untuk mengumpulkan data tersebut adalah berupa angket yang disebarkan kepada siswa-siswi yang mengikuti kegiatan ekstrakurikuler bolavoli tersebut.

\section{HASIL PENELITIAN}

\section{Deskripsi Data}

Deskripsi data yang dilakukan dalam penelitian ini adalah untuk melihat karakteristik distribusi data dari variabel pertanyaan yang meliputi aspek tentang motivasi, peran guru penjas serta sarana dan prasarana.

\section{Motivasi Siswa}

Untuk melihat keadaan motivasi siswa dalam Pelaksanaan Ekstrakurikuler Bolavoli di Sekolah Dasar Negeri 85 Lubuklinggau, penulis memberikan 15 butir pertanyaan. Adapun hasil dari jawaban responden terhadap pertanyaan mengenai keadaan motivasi siswa disajikan dalam tabel di bawah ini:

Tabel 1

Distribusi Frekuensi Motivasi Siswa

\begin{tabular}{clcc}
\hline No & Kategori Jawaban & Jumlah (f) & Persentase (\%) \\
\hline 1 & Sangat Setuju & 272 & 60,44 \\
2 & Setuju & 110 & 24,44 \\
3 & Ragu-ragu & 46 & 10,22 \\
4 & Tidak Setuju & 22 & 4,89 \\
5 & Sangat Tidak Setuju & 0 & 0 \\
\hline & Jumlah & $\mathbf{4 5 0}$ & $\mathbf{1 0 0} \%$ \\
\hline
\end{tabular}

Berdasarkan tabel diatas, dapat disimpulkan bahwa motivasi siswa dalam pelaksanaan ekstrakurikuler Bolavoli adalah diklasifikasikan pada kategori cukup yaitu $60,44 \%$ terdapat pada kategori sangat setuju.

\section{Sarana dan Prasarana}

Untuk melihat keadaan sarana dan prasarana terhadap Pelaksanaan Ekstrakurikuler Bolavoli, penulis memberikan 5 butir pertanyaan. Adapun hasil dari jawaban responden terhadap pertanyaan mengenai keadaan sarana dan prasarana disajikan dalam tabel di bawah ini: 
Tabel 2

Distribusi Frekuensi Sarana dan Prasarana

\begin{tabular}{clcc}
\hline No & \multicolumn{1}{c}{ Kategori Jawaban } & Jumlah (f) & Persentase (\%) \\
\hline 1 & Sangat Setuju & $\mathbf{4 6}$ & $\mathbf{3 0 , 6 7}$ \\
2 & Setuju & $\mathbf{5 5}$ & $\mathbf{3 6 , 6 7}$ \\
3 & Ragu-ragu & $\mathbf{3 4}$ & $\mathbf{2 2 , 6 7}$ \\
4 & Tidak Setuju & $\mathbf{1 5}$ & $\mathbf{1 0}$ \\
5 & Sangat Tidak Setuju & $\mathbf{0}$ & $\mathbf{0}$ \\
\hline \multicolumn{2}{r}{ Jumlah } & $\mathbf{1 5 0}$ & $\mathbf{1 0 0} \%$ \\
\hline
\end{tabular}

Berdasarkan tabel diatas, dapat disimpulkan bahwa keadaan sarana dan prasarana dalam pelaksanaan ekstrakurikuler bolavoli adalah diklasifikasikan pada kategori baik, yaitu 30,67\% terdapat pada kategori sangat setuju

\section{PEMBAHASAN}

Berdasarkan hasil penelitian yang telah diuraikan di atas, variabel motivasi siswa, pelatih dan sarana dan prasarana merupakan faktor yang mendukung Pelaksanaan Ekstrakurikuler Bolavoli.

\section{Motivasi Siswa}

Pada tabel diatas dapat dilihat secara keseluruhan tingkat capaian motivasi siswa yang diperoleh sebesar $60 \%$. Artinya bahwa tingkat capaian motivasi siswa yang ada pada pelaksanaan ekstrakurikuler bolavoli di Sekolah Dasar Negeri 85 Lubuklinggau diklasifikasikan Cukup. Menurut (Arikunto, 1998) klasifikasi tingkat capaian antara 41-60\% berada pada kategori cukup. Motivasi siswa dalam pelaksanaan ekstrakurikuler bolavoli sangat dibutuhkan karena motivasi tersebut akan memberikan kepuasan tersendiri bagi siswa untuk mengikuti pelaksanaan ekstrakurikuler bolavoli.

Dari penjelasan di atas dapat kita simpulkan bahwa pembelajaran adalah kegiatan yang dilakukan diluar jam sekolah guna memperluas pengetahuan dan keterampilan siswa dalam menyalurkan bakat dan minatnya dimana kegiatan pembelajaran tersebut merupakan kegiatan penunjang dari kegiatan intrakurikuler sekolah. Tanpa motivasi yang cukup pendidikan jasmani maka akan sukar untuk mencapai tujuan yang diharapkan. Kesimpulannya adalah minat siswa merupakan salah satu aspek penunjang yang sangat penting di dalam pelaksanaan ekstrakurikuler bolavoli

Berdasarkan hasil tersebut di atas, jelas bahwa tanpa ada motivasi siswa yang cukup baik, hal ini berpengaruh terhadap kelancaran dalam pelaksanaan kegiatan pembelajaran sehingga dengan kurangnya motivasi, maka pelaksanaan ekstrakurikuler bolavoli tidak akan mencapai tujuan yang diinginkan. Jadi salah satu usaha untuk meraih hasil yang baik dalam pelaksanaan ekstrakurikuler bolavoli akan ditentukan oleh minat siswa terhadap kegiatan pembelajaran. Motivasi siswa pada pelaksanaan ekstrakurikuler bolavoli di sekolah dasar sudah mendukung, hanya saja perlu ditingkatkan lagi.

\section{Sarana dan Prasarana}

Pada tabel diatas dapat dilihat secara keseluruhan tingkat capaian sarana dan prasarana yang diperoleh sebesar $62 \%$. Artinya bahwa tingkat capaian sarana dan prasarana terhadap pelaksanaan ekstrakurikuler bolavoli di sekolah dasar pada 
klasifikasi baik. Menurut Arikunto (1998) bahwa klasifikasi tingkat capaian antara $61-81 \%$ berada pada kategori baik. Sarana dan prasarana merupakan salah satu penunjang dalam pelaksanaan pembelajaran. Kelengkapan sarana dan prasarana sangat menentukan dalam sukses atau tidaknya pembelajaran, tanpa sarana dan prasarana pendidikan akan mengalami kendala. Oleh sebab itu sarana dan prasarana merupakan alat vital bagi tercapainya prestasi. Sarana adalah alat atau peralatan yang digunakan atau diperlukan dalam melaksanakan kegiatan olah raga, seperti bola, raket, alat-alat senam, dayung, sepatu khususnya untuk olahraga tertentu. Prasarana adalah tempat lahan atau bangunan yang memenuhi persyaratan atau dinyatakan untuk melakukan olah raga.

Berdasarkan hasil tersebut di atas, jelas bahwa sarana dan prasarana sangat diperlukan dalam pelaksanaan pembelajaran guna mencapai tujuan yang diinginkan. Namun di Sekolah Dasar Negeri 85 Lubuklinggau sarana dan prasarana bolavoli sudah terpenuhi dengan baik, untuk itulah diharapkan agar lebih dapat memberikan sarana maupun prasarana baik dari segi kualitas maupun kuantitasnya. Dengan adanya sarana dan prasarana yang mencukupi dan layak pakai diharapkan pelaksanaan ekstrakurikuler bolavoli di sekolah dasar dapat berjalan dengan baik sehingga dapat mencapai tujuan yang diharapkan dan kegiatan pembelajaran bisa terlaksana secara optimal

\section{SIMPULAN}

Tingkat capaian motivasi siswa dalam pelaksanaan ekstrakurikuler bolavoli berada pada klasifikasi cukup, yaitu dengan tingkat capaian jawaban responden mencapai $60 \%$. Artinya bahwa untuk pelaksanaan ekstrakurikuler bolavoli, motivasi yang ada pada siswa masih dalam kategori cukup. tingkat capaian sarana dan prasarana dalam pelaksanaan ekstrakurikuler bolavoli berada pada klasifikasikan baik, yaitu dengan tingkat capaian sebesar $62 \%$, artinya bahwa sarana dan prasarana yang ada dalam pelaksanaan ekstrakurikuler bolavoli sudah Baik.

\section{DAFTAR PUSTAKA}

Arikunto, S. (1998). Prosedur Penelitian Suatu Pendekatan Praktek. Jakarta: Rineke Cipta

Erianti. (2004). Buku Ajar Bolavoli. Padang: FIK UNP

Fatahillah, A. (2018). Hubungan Kelincahan dengan Kemampuan Dribbling pada Siswa Ekstrakurikuler Bola Basket. Gelanggang Olahraga: Jurnal Pendidikan Jasmani Dan Olahraga (JPJO), 1(2), 11-20. https://doi.org/https://doi.org/10.31539/jpjo.v1i2.131

Sovensi, E. (2018). Ketepatan Smash Pemain Bolavoli Siswa SMA Ditinjau dari Koordinasi Mata-Tangan dan Extensi Togok. Gelanggang Olahraga: Jurnal Pendidikan Jasmani Dan Olahraga (JPJO), 2(1), 129-139. https://doi.org/https://doi.org/10.31539/jpjo.v2i1.406

Sovensi, E., Supriyadi, M., \& Suhdy, M. (2019). Kondisi Fisik Pemain Bola Voli Klub di Kota Lubuklinggau. Gelanggang Olahraga: Jurnal Pendidikan Jasmani Dan Olahraga (JPJO), 2(2), 13-25. https://doi.org/https://doi.org/10.31539/jpjo.v2i2.697 
Supriyanto, S. (2018). Pengaruh Metode Latihan Plyometric dan Latihan Beban dengan Kecepatan Reaksi terhadap Power Otot Tungkai Pemain Bolavoli Putra. Gelanggang Olahraga: Jurnal Pendidikan Jasmani Dan Olahraga (JPJO), 2(1), 176-189. https://doi.org/https://doi.org/10.31539/jpjo.v2i1.423

Umar, H. (1998). Metode Penelitian Untuk Skripsi dan Tesis. Jakarta: Raja Grafindo. Persada 